\title{
Contemporary Hakka Language Maintenance in Multilingual Penang, Malaysia
}

\author{
Teresa Wai See Ong ${ }^{1}$ \\ School of Humanities, Languages and Social Science, Griffith University, Australia
}

Abstract: Malaysia is a multilingual country with 134 languages widely spoken. Among the Chinese community, which is the second largest ethnic group in Malaysia, Mandarin Chinese has become the mother tongue in recent years as many claimed it represents their Chinese identity. Additionally, the influence of mass media and the use of Mandarin Chinese as the main medium of instruction in Chinese-medium primary schools have motivated parents to shift from speaking Chinese heritage languages to Mandarin Chinese to their children at home. This shift has caused sociolinguistic realignment within many Chinese families in Malaysia and, ultimately, erased various language backgrounds. Like other Chinese heritage languages in Malaysia, Hakka currently faces many challenges in terms of language maintenance. To ensure its survival in Malaysia, it is vital to examine the current linguistic situation of Hakka. Addressing this gap, this study examines language practices, ideology, and community-based initiatives to maintain Hakka in Penang and provides new insights into the process and prospects for language maintenance.

Keywords: Hakka; Language maintenance; Heritage languages; Penang; Malaysia.

Título: Manutenção contemporânea da língua Hakka na multilíngue Penang, Malásia

Resumo: A Malásia é um país multilíngue com 134 línguas amplamente faladas. Na comunidade chinesa, que é o segundo maior grupo étnico na Malásia, o chinês mandarim tem recentemente se tornado a língua materna, pois, como muitos afirmam, ela representa a sua identidade chinesa. Além disso, a influência da mídia de massa e o uso do chinês mandarim como o principal meio de instrução nas escolas primárias chinesas motivaram os pais a falar chinês mandarim com os seus filhos em casa e não mais as línguas de herança chinesas. Essa mudança causou um realinhamento sociolinguístico em muitas famílias chinesas na Malásia e, ultimamente, apagou backgrounds linguísticos. Como outras línguas de herança chinesas na Malásia, Hakka encara atualmente muitos desafios em termos da sua manutenção. Para garantir a sua sobrevivência na Malásia, é vital examinar a sua situação linguística atual. Ao abordar essa lacuna, este estudo examina as práticas linguísticas, ideologias e as iniciativas da comunidade para manter Hakka em Penang e fornece novas ideias sobre o processo e perspectivas para a manutenção da língua.

Keywords: Hakka; Manutenção linguística; Línguas de herança; Penang; Malaysia.

\footnotetext{
${ }^{1}$ PhD (Griffith University, Australia). Orcid: https://orcid.org/0000-0001-6723-589X. Email: ongtesa@gmail.com.
} 


\section{Introduction}

Language plays an important role in the everyday lives of people around the world. In a community setting, a heritage language acts as the means of communication, particularly for the older generation. With the growth of global languages such as English and Mandarin Chinese in the modern era, heritage languages have become weaker in their functional range - they are losing their status and presence as a prestige language in the community and consequently becoming languages only spoken by the older generation. Heritage languages have to compete with global languages for survival, particularly in big cities. Moreover, as their lexis, morphology, and syntax are influenced by global languages, their use becomes restricted to certain domains.

In recent years, concern for the loss of heritage languages has been demonstrated at national, regional, and community levels in diverse locations such as New Zealand, Ireland, and Alaska. Numerous programs have been initiated and found to be relatively successful in 'rescuing' some heritage languages from further decline, while others return as mother tongues in the community. However, Fishman (1991) states that some initiatives were unsuccessful because they focused too much on educational institutions to promote and transmit language maintenance. Advocates for heritage languages have tended to leave their hopes for reinstatement to the educational institutions, as they believed school programs can either influence or threaten language maintenance (Fishman, 1991; Hornberger \& King, 1996). Such a tendency has demonstrated an overall lack of success in terms of the sociocultural process of language maintenance. McCarty (2008, p. 61) also claims that "schools are secondary to the primary language implanting and expanding institutions of family and community". As the literature shows limited studies have focused on community-based initiatives; thus, this paper seeks to restore a balance by exploring this issue.

The Hakka community in Penang, Malaysia is among those communities facing such a situation because their heritage language, Hakka, is being threaten by global languages and its usage is limited to the home and family domains (Ding \& Goh, 2017; Wang, 2017). Therefore, in considering the case of the Hakka community, this study offers insight into language practices and ideologies, and community-based initiatives to maintain Hakka in Penang. Data were collected through formal interviews with six participants representing the Hakka community. Analysis suggests that language maintenance must be understood as a process that depends on the cultural orientation of the community and the extent to which language is embedded in their ethnic identity.

\section{Literature Review}

Language maintenance and language shift is a complex field of inquiry in sociolinguistics. It was initiated by Joshua A. Fishman in the 1960 s and then expanded to include other disciplines such as sociology, psychology, anthropology, and political science. Language shift can be defined as a process of replacing a language with another as a mean of 
communication and socialisation at both individual and community levels. This situation leads to the favouring of a dominant language and loss of the first language for individuals and their community. Conversely, language maintenance is a process by which a community decides to continue using the language or languages it has traditionally used. In some cases, individuals of the community arrive in a new linguistic environment but continue to use their first language, while in other cases they become bilingual, adapting to use both their first language and the language of the new environment. In such situations, language maintenance takes place even though use of the first language may be restricted to certain domains.

According to Berardi-Wiltshire (2017), the field of language maintenance and language shift has always been associated with language planning and policy (LPP), because language maintenance programs usually involve some degree of planning and regulation. Traditionally, language maintenance programs are largely staged at the national level where LPP are imposed by governments and national institutions through a top-down process. Hence, there is a significant amount of language maintenance literature that deals with the issues and effects of LPP and the role of education (cf. Romaine, 2007). Recently, there has been a shift in the approach taken by scholars that demonstrates language maintenance programs are taking place at different societal levels, from government to community and family domains, through a bottom-up process (cf. Blommaert, 2006; Canagarajah, 2006). As a result of this change in approach, scholars have begun to expand their scope of investigation to include micro-level LPP. Subsequently, this change has expanded the research scope in search of complex relationships between LPP and language maintenance programs.

The recent emergence of language maintenance and language shift as a "worldwide, grassroots and interdisciplinary movement" (Hermes, 2012, p. 131) is associated with the rising awareness of the loss of languages globally. With the current trend of LPP that involves inquiries into different disciplines and conceptual frameworks, it is clear that the scholarship today has shifted to conceptualise LPP as a complex phenomenon involving both official governmental legislations and unofficial community and family language policies. In addition, the growing body of literature has emphasised that language ideology and power dynamics play a significant role in the process of language contact and have contributed to the disappearance of languages (Berardi-Wiltshire, 2017). In understanding the concept of LPP, language planning is related to the deliberate activities carried out by governmental agencies, while language policy is associated with the establishment of laws and regulations aimed at changing language behaviour in a community (cf. Kaplan \& Baldauf, 1997). Nevertheless, in reality, the boundaries of LPP are less clear as they cover four types of language planning: status planning, corpus planning, prestige planning, and acquisition planning (cf. Cooper, 1989; Fishman, 1974; Haugen, 1983; Hornberger, 1994; Kaplan \& Baldauf, 1997; Nahir, 1984). As Hornberger $(1994,2006)$ argues, the LPP of a language maintenance program does not occur in a vacuum, because language ideology, agencies, and ecology are constantly involved.

Ricento (2000, p. 208) claims that postmodern scholarship, such as Pennycook (2006), has demonstrated the relationship between LPP and language ideology, and suggests that "the key variable which separates the older, positivistic/technicist approaches from the 
newer critical/postmodern ones is agency, that is, the role(s) of individuals and collectivities in the processes of language use, attitudes, and ultimately policies". Pennycook (2013) states that a community's ideology plays a role in influencing how languages are regulated in the society. Indeed, we have observed increasing contributions of LPP that called for greater attention to the role of human agencies (cf. Canagarajah, 2002; Ricento \& Hornberger, 1996), language ecology (cf. Fill \& Mühlhaüsler, 2001; Phillipson \& Skutnabb-Kangas, 1996), and language ideology (cf. Shohamy, 2006; Zavala, 2004). Taking into account such an emphasis, LPP has moved forward in this contemporary era. As Ricento (2006, p. 10) argues "there is no overarching theory of LPP, in large part because of the complexity of issues which involve language in society".

Given the literature has demonstrated that LPP is made up of a number of complex issues, Spolsky's (2007) conceptualisation of what LPP comprises is fairly accurate. Spolsky frames LPP as a three-part component:

a) language practices, which is concerned with the everyday use of a specific language or language variety in a speech community

b) language ideology or beliefs, which is concerned with beliefs about language and language use in the society

c) language management, which is concerned with the specific efforts made by authorities to influence language practices.

As Albury (2016) states, Spolsky's LPP framework has been built within the multidisciplinary perspectives of the current LPP research trend. It therefore invites scholars to examine how government authorities intervene in language maintenance programs and how communities' and grassroots' ideologies influence everyday language use. The next section turns to present the sociolinguistic background and language policy of Malaysia.

\section{Context of Malaysia}

Located in Southeast Asia, modern Malaysia is a country that represents a rich linguistic and cultural diversity (Asmah, 1992). Made up of Peninsular Malaysia and the states of Sabah and Sarawak, it has a population of 32.6 million (Department of Statistics, 2019a) with three major ethnic groups living together. The ethnic groups are Malays, Indigenous people, and natives of Sabah and Sarawak (69.3\%), Chinese (22.8\%), and Indians (6.9\%), while the remaining $1 \%$ is formed by other ethnic groups. Resulting from its historical process, favouritism for linguistic plurality has been created and resulted in ethnic mixing and cultural hybridisation in Malaysia (Petrü, 2017). The prioritising of Malays and other Indigenous people in the country's policy has been harmful influence in interethnic relations and a hindrance for social and economic progress. Nevertheless, Malaysia's greatest achievement of interethnic harmony is demonstrated through its peaceful relationship between ethnic groups, which in many ways is functionable, politically stable, and economically progressive. 


\section{History and language policy}

In 1771, the British colonized Malaya (previous name for Malaysia before independence). Keen on building a colonial economy in Malaya, the British initially recruited the Malays to work but later considered them to be unproductive (Andaya \& Andaya, 2016). In searching for a solution for the shortages in the workforce, the British brought in thousands of migrants from China and the Indian subcontinent to work in tin mines and rubber plantations. Another reason the British did so was because they were unwilling to teach the Malays the necessary skills, as they feared the Malays would learn to trade and rebel against them (Yeoh, 2006). The Malays therefore remained in the rice-growing regions while the Chinese and Indians moved into harbour cities such as Penang and Malacca. Consequently, Malaya's ethnocultural landscape was altered as it was divided according to ethnic groups and professions (Albury, 2019).

During the British colonisation period, English was the official language of Malaya and became the language of government administration and education for the elite groups, who were the rich Malays, Chinese businessmen, and Indian merchants. After Malaysia attained independence in 1957, English remained in use for another ten years and thereafter, it was phased out (Albury, 2018; Vollmann \& Soon, 2018). Bahasa Melayu, the language traditionally spoken by the Malays in the kingdoms of the Malay Archipelago, was instituted as the national language of Malaysia through Article 152 of the Federal Constitution and reinforced as the official language through the National Language Act 1963/1967. This institution was made to affirm the status of Malays in Malaysia and reinforce their self-identity, as despite forming the majority population, they faced many challenges (Albury, 2018). The most significant move in terms on language use was that all English schools were converted to national schools, where Bahasa Melayu became the sole language of instruction. To graduate from national schools, it was compulsory to pass Bahasa Melayu as a language subject. This codification of Bahasa Melayu as the national and official language of Malaysia supressed the value of English, which was commonly spoken by non-Malays in the country (Albury \& Aye, 2016). However, as globalisation unfolded and took hold, English was promoted as the medium of instruction for science and mathematics in schools through the policy of 'Teaching and Learning of Science and Mathematics in English' (Yang \& Md. Sidin, 2012). Today, it remains as the language of interethnic communication and local corporate and international economy (Jenkins, Cogo, \& Dewey, 2011).

Despite Bahasa Melayu having the highest linguistic capacity in Malaysia, the nonMalays were still entitled to language rights as stated in the Federal Constitution. For the Chinese, Mandarin Chinese was used as the main medium of instruction in Chinese-medium primary schools while for the Indians, Tamil was taught in Tamil-medium primary schools (Gill, 2014). In all secondary schools, the medium of instruction switched to Bahasa Melayu except in private schools. At the same time, heritage languages continued to be spoken, but mainly in the home domain. The Chinese speak Hokkien, Hakka, Cantonese, Teochew, Hainan, Taishan, and Fuzhou, while the Indians speak Hindi, Malayalam, Telugu, and Punjabi. In recent 
years, Mandarin Chinese has become the unofficial standard language for the Chinese community and thus, progressively spoken in the home domain (Wang, 2012; Ting \& Chang, 2008), while the Indians have shifted to speaking English due to the economic value it offers (Ting \& Mahadhir, 2009). In East Malaysia where Sabah and Sarawak lie, Indigenous languages such as Kadazan-Dusun, Bidayuh, Kelabit, Bajau, and Iban are also commonly spoken (Ghazali, 2010). In addition to these languages, a localised variety of English, commonly known as Manglish, is also widespread within different ethnic groups (David, 2003; Lau \& Ting, 2013).

While there is a diverse range of languages and traditions being practised in Malaysia, the modern nation is defined by law. Islam was established as the national religion of Malaysia, although other religious denominations, such as Buddhism, Taoism, Christianity, and Hinduism, are practised (Department of Statistics, 2018). The Malays, Indigenous people, and natives of Sabah and Sarawak were entitled to socioeconomic benefits such as tax breaks, and employment and university entrance quotas, which disadvantaged the other ethnic groups (Albury, 2017). Policy programmes such as Bangsa Malaysia were established to unite Malaysians based on citizenship rather than ethnicity (Ridge, 2004), and 1Malaysia sought to promote equality and meritocracy (Ong, 2018). The Sedition Act 1948 was also enacted to reinforce the strong favouritism for Bahasa Melayu and ensure this favouritism was not questioned (Coluzzi, 2017).

In short, conflicting language ideologies can be observed in the language policy of Malaysia. Despite holding a strong favouritism for Bahasa Melayu, which is the national and official language of Malaysia and traditionally spoken by the Malays, there is competition with English as the global language, Mandarin Chinese and Tamil as the standard language for the Chinese and Indian communities, and other heritage languages. Nevertheless, in recent years, this strict language policy has started to loosen up due to several factors, including the "privatisation of education and media services, increasing global economic competition, an amplified multicultural discourse, and the rise of China as an economic power" (Lee, 2009, p. 223).

\section{Chinese Settlement in Penang}

An area in Malaysia that has a long history of Chinese settlement is Penang, a state located in Northern Peninsular Malaysia, consisting of two parts, Penang Island and Seberang Perai. The establishment of Penang as a British colony can be traced back to the 18th century when Sir Francis Light founded Penang in 1786 and later declared George Town as a free trading port (Andaya \& Andaya, 2016). As a focal commerce point in the Malay Archipelago, Penang attracted many Chinese merchants to interact and trade with the Europeans and provided them the opportunities to expand their commercial activities (Wong, 2013). The flourishing trade eventually encouraged the Chinese merchants to set up shops and settle in Penang. In addition, the expansion of the tin mining industry in Perak brought in more Chinese labourers to work. Soon after, they moved to bigger cities such as Penang to seek better 
economic opportunities, establish families, and build homes. This movement resulted in Penang having Chinese as the dominant population ever since.

The Chinese community constituted $39.1 \%$ of Penang's 1.77 million population (Department of Statistics, 2019b). Practising similar language policies to Malaysia, the national and official language of Penang is Bahasa Melayu, which acted as the language of administration, law courts, and education. English is widely spoken by various ethnic groups and used in many private sectors, such as media, business, commerce, and education. Mandarin Chinese has progressively become the standard language for the Chinese community (Wang, 2012), and thus serves as the medium of instruction in Chinese-medium primary schools in Penang. Written Chinese is also seen on government- and grassrootsauthored signage around George Town (Ben Said \& Ong, 2019). Tamil is taught in Tamilmedium primary schools but spoken in the home domain. Other Chinese and Indian heritage languages are mainly used for social interactions with family and friends. Among the many Chinese heritage languages, Hokkien serves as the main language of communication for the Chinese due to the large Hokkien population among the Chinese in Penang ("Dialects and Languages", 2017; Wang, 2017). Hokkien is also learned by other ethnic groups for basic communication. Consequently, Hokkien plays a significant role in the linguistic scenery of Penang because it is an important marker of cultural identity of Penang (Ong, 2019).

\section{The Hakka community in Balik Pulau}

With the establishment of a large Chinese settlement in modern Penang since the 18th century, the Hakka population is estimated to be about 34,000 (Department of Statistics, 2010). Balik Pulau, a suburb located in the west of Penang Island, was home to the largest Hakka community. When Penang was under the British rule, about $41.7 \%$ of the Chinese population in Balik Pulau was Hakka (Wang, 2017). Today, there are still many Hakkas living in Balik Pulau (Wang, 2017).

In the early days, the Hakkas who arrived in Penang comprised three groups: the Jiaying Hakkas, the Dingzhou Hakkas, and the Huizhou Hakkas (Yen, 2017). In Balik Pulau, most of the Hakkas are from Huizhou (Chang \& Chang, 2011). They speak Hakka, together with other Chinese heritage languages, but their use of Hakka is restricted to the home domain (Wang, 2017). Hakka is not a written language (Vollmann \& Soon, 2018), which poses challenges in terms of development and heritage language education. The younger generation of Hakkas started to move to bigger cities like Kuala Lumpur or abroad for better job and study opportunities. As many did not know where their ancestors originated, they only claimed to be of Chinese origin (Wang, 2017). Moreover, due to exogamous marriages, which are commonly practised today, many young Hakkas are married to Chinese from other heritage language groups such as Hokkiens, Cantonese, and Teochews. As a result, they tend to speak Hokkien, the most widely spoken Chinese heritage language in Penang ("Dialects and Languages", 2017) or global languages like Mandarin Chinese and English. Due to the economic value Mandarin Chinese offers, many young Hakka parents are enrolling their 
children in Chinese-medium primary schools. Consequently, they tend to neglect Hakka and only speak global languages at home (Wang, 2017). Some older generation have also shifted to speaking Mandarin Chinese with their grandchildren to ensure they are able to communicate in the home and family domains (Wang, 2017). Although Bahasa Melayu is the national and official language in Penang and Malaysia, it is not commonly spoken by the Hakkas with other ethnic groups or among themselves (Tan, 2000). This situation is similar for the Indian community, which has reduced the use of Tamil and other Indian heritage languages and increased the use of English due to it being regarded as a language of internationalism (Ting \& Mahadhir, 2009). Summing up the linguistic scenery of the Hakka community in Balik Pulau, the older generation Hakkas generally speak Hakka together with other Chinese heritage languages and global languages in their daily lives, while the younger generation Hakkas have begun to ignore the use of Hakka and only focus on global languages.

\section{Methodological Considerations}

As mentioned above, the national and official language of Penang is Bahasa Melayu, which acts as a symbol of sovereignty for the state and country and is used as the main medium of instruction in national schools. As English maintains its importance in Penang, it acts as the unofficial language in various sectors and is taught in schools as a subject. Mandarin Chinese and Tamil are used as the main medium of instruction in Chinese- and Tamil-medium primary schools. In the home domain, the Chinese and Indians often speak their heritage languages, which allows them to preserve their linguistic heritage. Their heritage languages are also used in social, cultural, and religious functions. Although the language ideologies are established this way, in reality, heritage languages are competing with global languages in the home domain and their survival is threatened.

The Hakkas are among the many subethnic groups within the Chinese community. While they speak their heritage language, Hakka, with family and friends, the influence of global languages on the younger generation Hakkas led to a reduction in the use of Hakka in the home domain. This situation raises questions about the future of Hakka in Penang. The current study is conceptualised through the use of Spolsky's LPP framework (as explained above) and aims to examine the Hakka community's initiatives to maintain their heritage language. An interview-based qualitative study was crafted in response to following research questions:

(1) How does the Hakka community use Hakka in their daily life?

(2) What is their ideology towards Hakka?

(3) What community-based initiatives have been made to maintain Hakka?

\section{Data collection and analysis}

An ethical application was sought from the researcher's university human research ethics committee in May 2016. Once it was approved, data collection was conducted between 
August and September in Penang. The semi-structured interview questions encompassed Hakka language practices in daily life, the participants' ideology towards Hakka, and community-based initiatives to maintain Hakka. A total of six Hakka people were recruited for the interview using the purposeful and snow-ball sampling method. The main criterion for recruitment was that participants were able to speak Hakka and their age ranged between 40 and 70 years old. This age bracket was based on studies having shown that many younger generation Hakkas no longer speak Hakka (Wang, 2017). Each interview was carried in the participant's home and lasted for approximately an hour. Before conducting the interviews, consent was obtained from the participants to allow the researcher to record the interview.

Initially, the language planned for interview was English to align with the language in which the study findings would be published; however, one of the participants had difficulties speaking English and was more comfortable using Mandarin Chinese. Having explained to the participant that the researcher's Mandarin Chinese proficiency was limited, the participant kindly switched between English and Mandarin Chinese during the interview. Translanguaging took place in this context without the researcher's realisation that multilingual speakers are able to "creatively and strategically renegotiate the norms for voice" (Canagarajah \& Gao, 2019, p. 2).

After the interviews, all participants' names were removed for confidentiality purposes and labelled with a code before the recordings were transcribed. The basic information of the participants is listed in Table 1. There were no corrections to the morphosyntax in the transcripts in an effort to retain their authenticity. Content analysis in the form of thematic analysis was carried out by focusing on three components: daily language practices, ideology towards Hakka, and community-based initiatives. The findings reported in the following sections include some interview extracts.

Table 1: Demographic information of participants

\begin{tabular}{llll}
\hline Code & Gender & Occupation & Languages Spoken \\
\hline C1 & F & State assemblywoman & $\begin{array}{l}\text { Malay, English, Mandarin Chinese, Penang } \\
\text { Hokkien, Cantonese, Hakka }\end{array}$ \\
& M & State assemblyman & $\begin{array}{l}\text { Malay, English, Mandarin Chinese, Penang } \\
\text { Hokkien, Cantonese, Hakka }\end{array}$ \\
\hline C3 & M & Research fellow & Malay, English, Mandarin Chinese, \\
& & Cantonese, Hakka \\
\hline C4 & M & Director & $\begin{array}{l}\text { Malay, English, Mandarin Chinese, Penang } \\
\text { Hokkien, Cantonese, Hakka }\end{array}$ \\
\hline C5 & M & Principal & Malay, English, Mandarin Chinese, Penang \\
& & Hokkien, Cantonese, Hakka \\
\hline C6 & F & Chinese physician & $\begin{array}{l}\text { Malay, Mandarin Chinese, Penang Hokkien, } \\
\text { Cantonese, Hakka }\end{array}$ \\
\hline
\end{tabular}




\section{Findings}

\section{Daily language practices}

According to Fishman (1972) and Spolsky (2009), language practices should be observed in the family domain because it is where heritage languages are usually spoken and where children acquire them. Spolsky (2009) states that in the family domain, parents are in charge of making the decision for their children on the languages spoken. In other words, they play a role in creating the home language environment and planning various language-based activities, including reading a story in a certain language, watching certain channels on television, establishing language-motivated playgroups, and moving to a neighbourhood where they can obtain language support from the community. Pauwels (2005) adds that the family's immediate environment, such as relatives, friends, and colleagues, positively impact language transmission in the family domain. Such arguments are evidenced in the two excerpts below:

\section{Excerpt 1 by $\mathrm{C} 4$}

So in fact, indeed, I like talking especially in Hakka, I like talking to people who speak in their own community language. Yes, older generation yes, not the younger generation. Relatives like cousins and nephews, all among my generation. It's just like with family, you speak Hakka. Among my friends, if I know he is Hakka, I will talk to him in Hakka, even we are so-called educated, college trained and have seek higher education.

\section{Excerpt 2 by $\mathrm{C} 3$}

I come from a very Hakka (environment), I grew up in a very Hakka environment, my parents and friends speak Hakka. (In) my hometown, it's a very Hakka village, you got $80-90 \%$ of the residents there are Hakka.

Excerpt 1 shows C4 always speaks Hakka with his family members and friends who are of Hakka origin, while excerpt 2 demonstrates that C3's Hakka influence originated from the place he grew up-a Hakka village where his parents and friends spoke to him in Hakka. Both excerpts also support Fishman's (1999) statement that language and ethnicity are closely bound. Fishman (1999, p. 448) claims that language appears to be the most important key to defining ethnicity, "from an emphasis on culture, history, purported kinship, patrimony, and uniqueness it is but a short leap to language, the one behaviour system that combines, expresses, and symbolises all these ideas". Further, "only language could evoke a sense of continuity in the midst of modernity's constant discontinuity, of community in the midst of its influx of strangers" (Fishman, 1999, p. 452). Fishman's statement counters the example in excerpt 3, where $\mathrm{C} 5$ stated he regretted not learning Hakka from his parents when young as now he cannot teach his children Hakka: 


\section{Excerpt 3 by $\mathrm{C} 5$}

I can't speak good Hakka now. My children cannot speak Hakka but sometimes I will say why I can't speak, because last time my father and mother didn't speak with us. If they speak Hakka, now I can speak. So I regret.

Therefore, language practices hold an important key for language maintenance.

Besides speaking Hakka in the family domain, other participants also speak Hakka in the work domain. C4 explained that when he represented Penang's Hakka association for a business trip to Meizhou (the Hakka capital city in China), he spoke Hakka to the city's mayor and in television interviews. He said that the people in Meizhou praised his Hakka, commenting that he had accurate Hakka pronunciation and vocabulary despite originating from Malaysia, where the Hakka group is considered a small community. He added that when he speaks Hakka, he does not mix Bahasa Melayu or Hokkien vocabulary into his Hakka so that he can keep the language as 'pure' as possible. Although the language mixing phenomena is common in Malaysia (Asmah, 1992; Coluzzi, 2017), C4's cautiousness in using 'pure' Hakka in Meizhou demonstrates his deep metalinguistic knowledge. While C4 has the opportunity to use Hakka at work, C6 and C2 have less opportunities, as exemplified in the excerpts below:

Excerpt 4 by $\mathrm{C} 6$

Hardly, I hardly use Hakka because there are not many Hakka patients unless for those old patients whose Hokkien isn't good, then I will speak in Hakka.

Excerpt 5 by $\mathrm{C} 2$

In Cantonese clan function, I do sometimes deliver the whole speech in Cantonese, much to the surprise and pressure of hearing someone, even their own people can't speak. Hakka, occasionally yes, because I am Hakka. The opportunity to use Hakka is less especially in Penang. Cantonese also because of the television, the drama series and all that, so I think a lot of people understand Cantonese but not Hakka.

C6's excerpt shows that she does not have many Hakka patients but speaks Hakka when needed. In C2's case, Hokkien and Cantonese are seen as more prestigious than Hakka in Penang, mostly due to Hokkien being the most widely spoken Chinese heritage language in Penang (Ong, 2019) and Cantonese being heavily influenced by Hong Kong's entertainment industry since the 1970s (Law, 2016). Nevertheless, whenever C2 has the opportunity to give speeches in Hakka, he does so to represent himself as being of Hakka origin. Contrastingly, despite having Hakka origins, C1's knowledge of Hakka is limited. Consequently, she puts in conscious effort to learn and speak Hakka at work, as exemplified below:

Excerpt 6 by $\mathrm{C} 1$

I tried to learn Hakka to become closer to people. When people feel that we are from the same clique, it is easier for us to communicate and if you want to do something, it becomes easy. People can understand what you want and they can trust you. If people prefer to use Hakka, I will try to use it so that they can express what they want to me. As an assemblywoman, we must try to understand the 
people when they walk in, what is their focus, what they want. If they can't express what they want, you can't do anything.

C1's efforts to learn and speak Hakka is to ensure she can communicate with the grassroots people whom she represents, so she can help them and gain their trust. As Groff (2017) claims, language serves to bring closeness in a community and make one feel as though they belong, like in a family.

Hakka language practices are not restricted to speaking Hakka with family and friends and at work, but also include cultural maintenance. According to Elovitz and Kahn (1997), cultural transmission to children within families involves family members, national traditions, and social setting. Zhang (2008) adds that the exploration of culture is important for language maintenance because language and culture are inseparable. As evident in the current study, one of the participants held strong cultural values to support his daily language practice. An important value that he continues to pursue is naming his children according to his respective heritage language and not according to Mandarin Chinese pronunciation, which is illustrated in the following excerpt:

\section{Excerpt 7 by $\mathrm{C} 3$}

Well, that (naming culture) really reflects how many Chinese can still use their own language. From the name, you can see like now, like my daughter's, she has her Hakka name. So her friends were curious, why your name is pronounced very differently from because all theirs are pronounced according to pinyin, why your name cannot use pinyin to pronounce. I told her because yours is Hakka, I followed the Hakka intonation, so it came out like that. It's getting less and less of that (naming culture).

C3's excerpt represents the traditional culture that emphasises the importance of Hakka in reflecting his family identity. Due to the ongoing language shift, he predicts that as many parents are no longer following the traditional method for naming their children, this culture will die off and they will only retain their subethnic group's surname.

In short, the six participants of this study use Hakka in their daily activities, such as speaking Hakka to family and friends, using Hakka at work, learning Hakka for communication purposes, and naming children according to Hakka pronunciation. These individual efforts indicate that they are keen to maintain their heritage language in multilingual Penang.

\section{Ideology towards Hakka}

Gal (1998, p. 319) defines language ideology as "matters of human understandingideas, consciousness, and beliefs about the relation of language and talk to social life". Based on this definition, language ideology is understood as a set of beliefs about language and its use in a social context. Spolsky (2009) states that language ideology originates from language practices in a society. Although previous studies, such as Ding and Goh (2017) and Wang (2017), have shown that many young generation Hakkas are no longer speaking Hakka with 
their children, the findings in this study differ because the participants use Hakka in the home and work domains whenever there are opportunities. This is mostly due to the participants belonging to the older generation Hakkas. This section therefore focuses on their ideology towards Hakka.

According to Wang (2017), the Hakkas are famous for their determination and persistency in maintaining their heritage language, which they chose to sell lands inherited from ancestry rather than abandoned their language. She found a similar ideology held by some of the participants in her study, to whom speaking Hakka was an important component in retaining their Hakka identity. A related ideology was found among the participants in the current study:

\section{Excerpt 8 by $\mathrm{C} 1$}

I think language plays so much a role in helping people to define themselves an identity. So the loss of a language will ultimately, will most definitely be the loss of cultural practices as well.

\section{Excerpt 9 by $\mathrm{C} 3$}

I think it is important to maintain heritage languages, it is your identity as a Hakka or as a Hokkien or Teochew. Without knowing the language, you may lose your identity.

\section{Excerpt 10 by $\mathrm{C} 6$}

When you speak Chinese heritage languages you can know your ethnic group. If you are a Hakka and you speak Hakka, then you know your origin is Hakka. When your friends ask you regarding your origin, it is easy to introduce yourself as a Hakka. When they ask you about your village, you can immediately tell them where your village is in China. Some children do not know where their ancestral villages are in China. This is something very important, children should know where their ancestors came from in China and it is easily traced back through their spoken community languages.

As heritage languages have symbolic and cultural values, they play a role in retaining a community's identity and social class in multiracial and multicultural Malaysia. Similarly, for the Hakka community in Penang, their language represents their identity as Hakkas. It is vital for them to know the language spoken by their ancestors, clan group, and ancestors' village in China because they carry important information regarding their historical roots. Therefore, losing their language will erase the historical family background maintained by their ancestors. Studies such as Giles and Coupland (1991) and Gudykunst and Ting-Toomey (1990) have demonstrated that for any community, language and identity should not be separated because a language serves as "a symbol of ethnic identity and cultural solidarity" (Giles, Bourhis, \& Taylor, 1977, p. 307). The excerpts above support the connection between language and identity, as argued by Giles et al. (1977) that speaking Hakka is a representation of their Hakka identity. 


\section{Community-based initiatives to maintain Hakka}

McCarthy (2008) argues that language maintenance initiatives should be implanted by parents and community; that is, parents are in-charged with raising their children to become members of one or more speech communities. When children are raised speaking several languages, they become multilingual speakers, which gives them the opportunity to become members of several speech communities. Indirectly, language acts as a mean of communication to transfer cultural knowledge between children and the community. In countries like Australia and Sweden, policy is used to promote the dominant group's preferred language to ensure everyone communicates in that language. Nevertheless, with the advent of globalisation, an increase in linguistic diversity can now be observed those countries. In the case of Malaysia, where its history and language policy have created a unique multilingual and multicultural background, it is vital to ensure its linguistic diversity is preserved, as described in the excerpt below:

\section{Excerpt 11 by $\mathrm{C} 1$}

I guess it comes down to the need for a general appreciation what our heritage languages mean and I think for me, one of the reasons why we should, some efforts need to be put to maintain these heritage languages. As I said heritage languages are often associated with cultural practices. And I think ensuring this diversity, its necessary to ensure the different ways of thinking, different ways of perceiving the world and in our society now places on innovation, out-of-the-box thinking, on diversity of views, maintaining that culture diversity leans towards that as well, so it ensures that the people in our community, our youth continues having that different ways of thinking and perceiving the world and you don't get carbon copies students coming out from the schools.

Knowing that many younger generation Hakkas are not speaking Hakka, the Hakka community has begun to carry out some initiatives in an effort to maintain Hakka in Penang. First, one of the Hakka clan associations, the Federation of Ka Yin Chu Association of Malaysia, supports children and youth to attain Hakka by publishing a Hakka learning book. Entitled Mei Shui Xiang Ying: Mei Xian Ke Jia Hua Du Ben (translated as 'Hakka in Mei County: A Translated Textbook for Learning'), the book was written using Standard Chinese by a professor from Jiaying University in Guangdong province, China. The association confirmed they began selling it in 2017 together with an accompanying audio disc.

Second, some Chinese-medium schools have started to work with the Hakka associations to conduct Hakka-based after-school activities. In a Chinese-medium private school, the board of teachers who supports the learning of heritage languages including Hakka, have held meetings with respective clan associations to organise heritage language classes after school hours. They also planned for a heritage language singing competition. In another Chinese-medium primary school, the principal has allowed the Hakka association to conduct Hakka cultural session each Saturday for the Hakka students. 
Third, the Hakka community in Penang continues to serve traditional dishes as part of their culture. As Bessière (1998) states, food is an important emblem of the culinary heritage of a given community. The traditional dishes for the Hakkas are yong tao foo (bean curb filled with minced meat mixture), mui choy kau yuk (preserved mustard greens with pork belly), and yim kuk kai (salted baked chicken). According to C4, these Hakka dishes are commonly found in Malaysian kopitiam (Chinese coffee shops in Malaysia where Chinese cuisine is served) and are served with rice. The taste may have been altered to assimilate into Malaysia's multiracial culture and the style of preparation may have been simplified to cater to the younger generation. Despite Matondang's (2016) claim that the Chinese community in Malaysia has created a hybrid culture due to globalisation, these traditional dishes are still an important identity marker for the Hakkas.

Lastly, the Hakka clan associations are encouraging the society to participate in their associations and cultural events. According to $\mathrm{C} 2$, many clan associations, including the Hakkas', are promoting their heritage languages and urging the younger generation to join them because many old members have passed away, resulting in diminishing numbers of association members. In the past, when the Chinese immigrants arrived in Malaya, they joined clan associations so they could stick together and help one another in various ways, such as looking for accommodation, writing letters to families in China, and arranging funerals. However, with the advent of internet and social media, these clan association services are no longer needed. Thus, as C2 stated, the clan associations have shifted their goals and instead encourage the younger generation to form a youth wing in the association, which acts as a platform for leadership training. Following in his grandparents' and parents' footsteps, C3 explained that he joined the Hakka association in his hometown and was involved in a Hakkarelated project for work. $\mathrm{C} 6$ mentioned that she usually spends her free time watching opera and other cultural shows during festival seasons, including those related to the Hakka culture. C3's and C6's statements align with Brown's (1994) argument that the maintenance of heritage languages includes the maintenance of culture because language and culture are inextricable.

Thus, knowing that the use of Hakka has been reduced in recent years, the Hakka community in Penang has started some initiatives to maintain Hakka. Among them were publishing a Hakka book, Chinese-medium schools supporting activities related to learning Hakka outside school hours, serving traditional Hakka dishes, encouraging the young generation to join the Hakka associations and take up leadership, and spending time to watch Hakka cultural shows.

\section{Conclusion}

As globalisation is shrinking today's world and society offers more opportunities to learn global languages, research into heritage languages requires more attention because these changes threaten their survival. Similarly, in Malaysia, previous studies have demonstrated that many younger generation Chinese have reduced their use of Chinese 
heritage languages because they focus on using global languages such as Mandarin Chinese and English due to the economic values these languages offer. As Hakka is one of the many Chinese heritage languages facing similar fate, this study examined its linguistic situation through interviews with six Hakka participants in Penang. Conceptualising the study using Spolsky's (2007) LPP framework, the findings revealed that the six participants use Hakka for social interactions in the family and home domains and whenever there is an opportunity at work. Their main reason for doing so related to the use of Hakka as a way to retain their Hakka identity in multiracial Penang. Because many younger generation Hakkas are no longer speaking Hakka, several community-based initiatives have been implemented to maintain Hakka.

The limitation of this study lies in it being a small-scale study with only six participants; therefore, the findings cannot be generalised. There may be participants who meet the same recruitment criteria but have different language practices and ideologies towards Hakka. Certainly, heritage languages like Hakka that do not have a writing system face isolation due to their limited use in the family and home domains and may ultimately die out. Nevertheless, the findings of this study demonstrated the close connection between heritage languages and identity in a multilingual context. They exemplify that heritage language maintenance will not be possible unless it is initiated in the family and home domains because parents are responsible for creating their children's linguistic identity. This issue therefore deserves further attention in terms of rethinking the cultural value of heritage languages.

\section{Acknowledgement}

The author would like to thank Prof. Ralf Vollmann and the two anonymous reviewers for their comments on the earlier draft. A special thanks to the Hakka community in Penang for their collaboration time. All remaining mistakes are solely the responsibility of the author. Opinions expressed and conclusions arrived at are those of the author.

\section{Funding}

The collection of data for this study was supported by the Griffith University International Postgraduate Research Scholarship (GUIPRS) and the Griffith University Postgraduate Research Scholarship (GUPRS) under project number GU 2016/409.

\section{References}

Albury, N. J. (2016). National language policy theory: Exploring Spolsky's model in the case of Ireland. Language Policy, 15, 355-372. https://doi.org/10.1007/s10993-015-9357-z

Albury, N. J. (2017). Mother tongues and languaging in Malaysia: Critical linguistics under critical examination. Language in Society, 46, 567-589. https://doi.org/10.1017/S0047404517000239 
Albury, N. J. (2018). Linguistic landscape and metalinguistic talk about societal multilingualism. International Journal of Bilingual Education and Bilingualism. https://doi.org/10.1080/13670050.2018.1452894

Albury, N. J. (2019). Between public perception and government intent in national language policy. Current Issues in Language Planning, 20(2), 160-178. https://doi.org/10.1080/14664208.2018.1468963

Albury, N. J., \& Aye, K. K. (2016). Malaysia's national language policy in international theoretical context. Journal of Nusantara Studies, 1(1), 71-84. https://doi.org/10.24200/jonus.vol1iss1pp71-84

Andaya, B. W., \& Andaya, L. Y. (2016). A history of Malaysia ( $3^{\text {rd }}$ ed.). London: Palgrave. https://doi.org/10.1057/978-1-137-60515-3

Asmah, H. O. (1992). The linguistic scenery in Malaysia. Kuala Lumpur: Dewan Bahasa dan Pustaka.

Ben Said, S., \& Ong, T. W. S. (2019). Tracing linguistic changes on shop signs in Malaysia: A diachronic examination of George Town, Penang. Socjolingwistyka Yearbook, 33, 225-246. https://doi.org/10.17651/SOCJOLING.33.13

Beradi-Wiltshire, A. (2017). Endangered languages in the home: The role of family language in the revitalisation of indigenous language. Revista Linguística, 13(1), 328-348.

Bessière, J. (1998). Local development and heritage: Traditional food and cuisine as tourist attractions in rural areas. European Society for Rural Society, 38(1), 21-34. https://doi.org/10.1111/1467-9523.00061

Blommaert, J. (2006). Language policy and national identity. In T. Ricento (Ed.), An introduction to language policy: Theory and method. (pp. 238-254). Victoria: Blackwell Publishing.

Brown, H. D. (1994). Principles of language learning and teaching. New Jersey: Prentice Hall.

Canagarajah, S. (2002). Celebrating local knowledge on language and education. A Special Issue of the Journal of Language, Identity, and Education, 1(4). https://doi.org/10.1207/S15327701JLIE0104 1

Canagarajah, S. (2006). Ethnographic methods in language policy. In T. Ricento (Ed.), An introduction to language policy: Theory and method (pp. 153-169). Victoria: Blackwell Publishing.

Canagarajah, S., \& Gao, X. (2019). Taking translingual scholarship farther. English Teaching \& Learning, 43, 1-3. https://doi.org/10.1007/s42321-019-00023-4

Chang, H. P, \& Chang, W. A. (2011). Malaixiya fuluoshanbei de kejia zuqun fenxi [The analysis of Hakka group in Balik Pulau, Malaysia]. In X. Q. Huang (Ed.), Zuqun lishi yu wenhua: Kua yu yanjiu dongnanya he dongya [Ethnic group, history and culture: The cross-border studies in Southeast Asia and East Asia] (pp. 195-216). Singapore: National University of Singapore.

Coluzzi, P. (2017). Language planning for Malay in Malaysia: A case of failure or success? International Journal of the Sociology of Language, 244, 17-38. https://doi.org/10.1515/ijsl-2016-0055

Cooper, R. L. (1989). Language planning and social change. Cambridge: Cambridge University Press. 
David, M. K. (2003). Role and functions of code-switching in Malaysian courtrooms. Multilingua: Journal of Cross-Cultural and Interlanguage Communication, 22(1), 5-20. https://doi.org/10.1515/mult.2003.005

Department of Statistics. (2010). Population (Malaysian citizen) by ethnic detail (Chinese) and state.

Department of Statistics. (2018). Population distribution and basic demographic characteristic report 2010 (Updated: 05/08/2011).

Department of Statistics. (2019a). Current population estimates, Malaysia, 2018-2019.

Department of Statistics. (2019b). Population quick info.

Dialects and languages in numbers. (2017, May). Penang Monthly. Retrieved from https://penangmonthly.com

Ding, S. L., \& Goh, K. L. (2017). Family language practices of Chinese Hakka in East Malaysia. In W. A. Chang (Ed.), Hakka studies in Taiwan, Southeast Asia and the World (pp. 215-239). Hsinchu: National Chiao Tung University Press.

Elovitz, P. H., \& Kahn, C. (Eds.). (1997). Immigrant experiences: Personal narrative and psychological analysis. Madison: Fairleigh Dickinson University Press.

Fill, A., \& Mühlhaüsler, P. (Eds.). (2001). The ecolinguistics reader: Language, ecology and environment. New York: Continuum.

Fishman, J. A. (1972). The relationship between micro- and macro-sociolinguistics in the study of who speaks what language to whom and when. In J. B. Pride \& J. Holmes (Eds.), Sociolinguistics: Selected readings (pp. 15-32). Harmondsworth: Penguin. https://doi.org/10.1515/9783111583600

Fishman, J. A. (1974). Language planning and language planning research: The state of the art. In J. A. Fishman (Ed.), Advances in language planning (pp. 15-33). The Hague: Mouton.

Fishman, J. A. (1991). Reversing language shift: Theoretical and empirical foundations of assistance to threatened languages. Clevedon: Multilingual Matters.

Fishman, J. A. (1999). Concluding comments. In J. A. Fishman (Ed.), Handbook of language and ethnic identity (pp. 444-454). Oxford: Oxford University Press.

Gal, S. (1998). Multiplicity and contention among language ideologies: A Commentary. In B. Schieffelin, K. Woolard \& P. Kroskrity (Eds.), Language ideologies: Practice and theory (pp. 317-347). New York: Oxford University Press.

Ghazali, K. (2010, November). National Identity and Minority Languages. UN Chronicle: The Magazine of the United Nations, 47(3) [Blog post]. Retrieved from http://unchronicle.un.org/article/national-identity-and-minority-languages/. https://doi.org/10.18356/f3ee6e9c-en

Giles, H., Bourhis, R., \& Taylor, D. (1977). Toward a theory of language in ethnic group relations. In H. Giles (Ed.), Language, ethnicity, and intergroup relations (pp. 307-348). London: Academic Press.

Giles, H., \& Coupland, N. (1991). Language: Contexts and consequences. Pacific Groove: Brooks/Cole Publishing Company. 
Gill, S. K. (2014). Language Policy Challenges in Multi-Ethnic Malaysia. Netherlands: Springer. https://doi.org/10.1007/978-94-007-7966-2

Government of Malaysia. (1948). Sedition Act. Kuala Lumpur: The Commissioner of Law Revision, Malaysia.

Government of Malaysia. (1957). Federal Constitution of Malaysia. Kuala Lumpur: The Commissioner of Law Revision, Malaysia.

Government of Malaysia. (1963/1967). National Language Acts. Kuala Lumpur: The Commissioner of Law Revision, Malaysia.

Groff, C. (2017). The ecology of language in multilingual India: Voices of women and educators in the Himalayan foothills. London: Palgrave Macmillan.

Gudykunst, W., \& Ting-Toomey, S. (1990). Ethnic identity, language, and communication breakdowns. In H. Giles \& P. Robinson (Eds.), Handbook of language and social psychology (pp. 309-327). New York: Wiley.

Haugen, E. (1983). The implementation of corpus planning: Theory and practice. In J. Cobarrubias \& J. A. Fishman (Eds.), Progress in language planning: International perspectives (pp. 269-289). Berlin: Mouton.

Hermes, M. (2012). Indigenous language revitalization and documentation in the United States: Collaboration despite colonialism. Language and Linguistics Compass, 6(3), 131 142. https://doi.org/10.1002/Inc3.327

Hornberger, N. H. (1994). Literacy and language planning. Language and Education, 8(1-2), 7586. https://doi.org/10.1080/09500789409541380

Hornberger, N. H. (2006). Frameworks and models in language planning and policy research. In T. Ricento (Ed.), An introduction to language policy: Theory and method (pp. 24-41). Victoria: Blackwell Publishing.

Hornberger, N. H., \& King, K. A. (1996). Language revitalisation in the Andes: Can the schools reverse language shift? Journal of Multilingual and Multicultural Development, 17(6), 427441. https://doi.org/10.1080/01434639608666294

Jenkins, J., Cogo, A., \& Dewey, M. (2011). Review of developments in research into English as a lingua franca. Language Teaching, 44(3), 281-315. https://doi.org/10.1017/S0261444811000115

Kaplan, R. B., \& Baldauf, R. B. Jr. (1997). Language planning: From practice to theory. Clevedon: Multilingual Matters.

Law, A. M. (2016, March 13). I know Hong Kong is over-because my mother has stopped watching TVB. Quartz. Retrieved from https://qz.com/629364/i-know-hong-kong-is-overbecause-my-mother-has-stopped-watching-tvb/

Lau, Y. L., \& Ting, S. H. (2013). Chinese vendors' code-switching in service counters in Sarawak, Malaysia. Sociolinguistic Studies, 7(3), 199-223. https://doi.org/10.1558/sols.v7i3.199

Lee, H. G. (2009). Language, education and ethnic relations. In L. T. Ghee, A. Gomes \& A. Rahman (Eds.), Multiethnic Malaysia (pp. 223). Petaling Jaya: SIRD. 
Matondang, S. A. (2016). The revival of Chineseness as a cultural identity in Malaysia. Khazar Journal of Humanities and Social Sciences, 19, 56-70. https://doi.org/10.5782/22232621.2016.19.4.56

McCarty, T. L. (2008). Schools as strategic tools for indigenous language revitalization: Lessons from native America. In N. H. Hornberger (Ed.), Can schools save indigenous languages? Policy and practice on four continents (pp. 161-180). Basingstoke: Palgrave. https://doi.org/10.1057/9780230582491 9

Nahir, M. (1984). Language planning goals: A classification. Language Problems and Language Planning, 8(3), 294-327. https://doi.org/10.1075//plp.8.3.03nah

Ong. T. W. S. (2018). Language maintenance in Malaysia: A case study of the Chinese community in Penang (Unpublished doctoral thesis). Griffith University, Australia.

Ong, T. W. S. (2019). Languages of the world: Penang Hokkien. Babel: The Language Magazine, $27,22-23$.

Pauwels, A. (2005). Maintaining the community language in Australia: Challenges and roles for families. International Journal of Bilingual Education and Bilingualism, 8(2), 124-131. https://doi.org/10.1080/13670050508668601

Pennycook, A. (2006). Postmodernism in language policy. In T. Ricento (Ed.), An introduction to language policy: Theory and method (pp. 60-76). Victoria: Blackwell Publishing. https://doi.org/10.1075/wlp.4.02pen

Pennycook, A. (2013). Language policies, language ideologies and local language practices. In L. Wee, R. Goh, \& L. Lim (Eds.), The politics of English: South Asia, Southeast Asia and the Asia pacific (pp. 1-18). Amsterdam: John Benjamins.

Petrů, T. (2017): A curious trajectory of interrace relations: The transformation of cosmopolitan Malay port polities into the multiethnic divisions of modern Malaysia. Asian Ethnicity, 19(1), 59-80. https://doi.org/10.1080/14631369.2017.1307688

Phillipson, R., \& Skutnabb-Kangas, T. (1996). English only worldwide or language ecology? TESOL Quarterly, 30(3), 429-452. https://doi.org/10.2307/3587692

Ricento, T. (2000). Historical and theoretical perspectives in language policy and planning. Journal of Sociolinguistics, 4(2), 196-213. https://doi.org/10.1111/1467-9481.00111

Ricento, T. K. (2006). An introduction to language policy: Theory and method. Victoria: Blackwell Publishing.

Ricento, T. K., \& Hornberger, N. H. (1996). Unpeeling the onion: Language planning and policy and the ELT professional. TESOL Quarterly 30(3), 401-427. https://doi.org/10.2307/3587691

Ridge, B. (2004). Bangsa Malaysia and recent Malaysian English language policies. Current Issues in Language Planning, 5(4), 407-423. https://doi.org/10.1080/14664200408668266

Romaine, S. (2007). Preserving endangered languages. Language and Linguistics Compass, 1(1-2), 115-132. https://doi.org/10.1111/j.1749-818X.2007.00004.x

Shohamy, E. G. (2006). Language policy: Hidden agendas and new approaches. New York: Routledge. https://doi.org/10.4324/9780203387962 
Spolsky, B. (2007). Towards a theory of language policy. Working Papers in Educational Linguistics, 22(1), 1-14.

Spolsky, B. (2009). Language management. Cambridge: Cambridge University Press.

Tan, C. B. (2000). Socio-cultural diversities and identities. In K. H. Lee \& C. B. Tan (Eds.), The Chinese in Malaysia (pp. 37-70). Kuala Lumpur: Oxford University Press.

Ting, S. H., \& Chang, Y. S. (2008). Communication in a close-knit extended Hakka family in Kuching, Sarawak: Mandarin or Hakka? In Proceedings of $9^{\text {th }}$ Borneo Research Council. Kota Kinabalu: Borneo Research Council. https://doi.org/10.2104/aral0911

Ting, S. J., \& Mahadhir, M. (2009). Towards homogeneity in home languages: Malay, Chinese Foochow and Indian Tamil families in Kuching, Sarawak, Malaysia. Australian Review of Applied Linguistics, 32(2).

Vollmann, R., \& Soon, T. W. (2018). Chinese identities in multilingual Malaysia. Grazer Linguistische Studien, 89, 35-61.

Wang, X. M. (2012). Mandarin spread in Malaysia. Kuala Lumpur: University of Malaya Press.

Wang, X. M. (2017). Family language policy by Hakkas in Balik Pulau, Penang. International Journal of the Sociology of Language: Special Issue on Language Planning and Multilingual Malaysia, 224, 87-118.

Wong, Y. T. (2013). Baba Hokkiens, big business, and economic dominance in Penang and its region, 1840s-1900s. Malaysian Journal of Chinese Studies, 2(2), 65-76.

Yang, L. F., \& Md. Sidin, A. I. (2012). Framing controversy over language policy in Malaysia: The coverage of PPSMI reversal (teaching of Mathematics and Science in English) by Malaysian newspapers. Asian Journal of Communication, 22(5), 449-473. https://doi.org/10.1080/01292986.2012.701312

Yen. C. H. (2017). Ethnicities, personalities and politics in the ethnic Chinese worlds. Singapore: World Scientific Publishing.

Yeoh, C. R. (2006). Malaysia, truly Asia? Religious pluralism in Malaysia. Harvard: Harvard University.

Zavala, V. (2014). An ancestral language to speak with the "other": Closing down ideological spaces of a language policy in the Peruvian Andes. Language Policy, 13(1), 1-20. https://doi.org/10.1007/s10993-013-9297-4

Zhang, D. (2008). Between two generations: Language maintenance and acculturation among Chinese immigrant families. El Paso: LFB Scholarly Publishing.

Received: October 05, 2019.

Accepted: November 20, 2019. 